\title{
TIMELY APPLICATION OF HEARING AIDS HELPS PRESERVE SPEECH DISCRIMINATION ABILITY
}

Contributions:

A Study design/planning

C Data analysis/statistics

C Data analysis/statistics

D Data interpretation

E Preparation of manuscrip

F Literature analysis/search

$\mathrm{G}$ Funds collection

\section{Susan Abdi ${ }^{A-G}$}

Hearing, Tehran University of Medical Sciences, Iran

Corresponding author: Susan Abdi, Hearing, TUMS, 3rd Floor - 37 Bahareshiraz St, Shariati Ave, 1565774419 Tehran, Iran; email: susanabdi2000@gmail.com, tel. +989121499920

\begin{abstract}
Background: Hearing damage has been related to certain brain conditions, particularly cognitive impairment. Hearing aids are commonly prescribed to compensate for hearing loss. In the current study, the time from when a hearing aid was first used by a patient was studied in terms of their speech discrimination ability in comparison with matched individuals who used no hearing aids.

Material and methods: Some 204 patients were enrolled and classified into two groups: 102 patients willing to use a hearing aid as soon as their hearing loss was diagnosed (Aided Group) and 102 patients who were also diagnosed with hearing loss but did not adopt hearing aids (Unaided group). The mean hearing threshold (HT) at octave intervals from 125 to $8000 \mathrm{~Hz}$, speech reception threshold (SRT), and speech discrimination score (SDS) were compared between the two groups of patients at 18 and 36 months.

Results: According to measurements 36 months after a patient's first attendance, patients who did not use a hearing aid immediately had significantly lower SDS scores compared to patients who decided to use hearing aids early on. This clearly demonstrates that timely application of hearing aids can prevent the loss of speech perception capabilities.

Conclusions: It is suggested that the golden time for hearing aid application is important. Hearing aids worn during the early stages of hearing loss can lead to improved speech discrimination ability. If there is hearing loss while discrimination is good ( $80 \%$ or higher), a hearing aid will be very useful. However, if discrimination is poor the results will not be as good.
\end{abstract}

Key words: hearing loss • hearing aid $\bullet$ speech perception $\bullet$ speech discrimination

\section{WCZESNE ZASTOSOWANIE APARATÓW SŁUCHOWYCH POMAGA W ZACHOWANIU ZDOLNOŚCI ROZRÓŻNIANIA MOWY}

\section{Streszczenie}

Wprowadzenie: Uszkodzenie słuchu związane jest z niektórymi stanami mózgu, szczególnie zaburzeniami poznawczymi. Aparaty słuchowe są zalecane pacjentom w celu zrekompensowania utraty słuchu. W niniejszej pracy badano zależność czasu kiedy pacjent po raz pierwszy użył aparatu słuchowego i umiejętności rozpoznawania mowy w porównaniu z osobami, które nie używały aparatów słuchowych.

Materiał i metody: Do badania zakwalifikowano około 204 pacjentów i podzielono ich na dwie grupy: 102 pacjentów chętnych do korzystania $\mathrm{z}$ aparatu słuchowego, gdy tylko zdiagnozowano u nich ubytek słuchu (grupa z aparatami) oraz 102 pacjentów, u których zdiagnozowano utratę słuchu, ale nie przyjęli aparatów słuchowych (grupa bez aparatów). Średni próg słyszenia (HT) w odstępach oktawowych od $125 \mathrm{do} 8000 \mathrm{~Hz}$, próg rozpoznawania mowy (SRT) i wynik rozróżniania mowy (SDS) porównywano między dwiema grupami pacjentów po 18 i 36 miesiącach.

Wyniki: Według pomiarów 36 miesięcy po pierwszej wizycie, pacjenci, którzy nie używali aparatu słuchowego, od razu mieli znacznie niższe wyniki SDS w porównaniu z pacjentami, którzy zdecydowali się na wczesne korzystanie z aparatów słuchowych. To wyraźnie pokazuje, że zastosowanie aparatów słuchowych jak najszybciej po rozpaczaniu niedosłuchu może zapobiec utracie zdolności rozpoznawania mowy.

Wnioski: Sugeruje się, że zastosowanie aparatu słuchowego odpowiednio jak najszybciej po rozpoznaniu niedosłuchu jest ważnym czynnikiem. Aparaty słuchowe noszone we wczesnych stadiach ubytku słuchu mogą prowadzić do poprawy zdolności rozpoznawania mowy. Jeśli występuje ubytek słuchu przy dobrej rozpoznawalności ( $80 \%$ lub więcej), aparat słuchowy będzie bardzo przydatny. Jeśli jednak rozpoznawalność jest niska, wyniki nie będą tak dobre.

Słowa kluczowe: ubytek słuchu • aparat słuchowy • rozpoznawanie mowy • rozróżnianie mowy

\section{Background}

Hearing loss is a growing health challenge and is a commonly undervalued disorder of sensory function $[1,2]$. Approximately $50 \%$ of people suffer from hearing loss with an increasing trend with age [3]. Subjects with a hearing disability are common and suffer major problems in daily life because of difficulties in communication, speech recognition, and language acquisition [4]. It has been reported that the disorder can disturb cognitive, social, and physical functions, as well as general quality of life. Additionally, hearing damage is undoubtedly related to dementia and depression [1].

Independent studies on hearing loss and cognitive impairment in elderly people have been conducted for many years. Nevertheless, the connection between hearing and cognition, and the probable mechanisms behind this connection, 
is of keen interest [5]. Peripheral hearing loss has also been significantly correlated with cognitive impairment, accelerated cognitive weakening, and dementia [6].

Hearing damage causes degradation of the internal representation of auditory stimuli [7]. This leads to various problems encountered regularly by hearing-impaired listeners, since effective speech recognition needs correct decoding of acoustic signals [8]. In daily life, speech is usually heard along with different types of background sounds, and noisy environments increase the challenge of effective communication [9]. Research suggests that, in comparison with normal people, the speech perception performance of hearing-impaired listeners is severely compromised under adverse listening conditions [10]. It has been proposed that processing and keeping track of continuous auditory streams increases cognitive load, making the listening task more difficult [11]. Consequently, people with impaired hearing need to try harder to attain successful speech perception [12]. Higher listening effort as a consequence of impaired hearing may lead to unfavorable psychosocial outcomes, such as higher levels of mental exhaustion and distress, shortage of energy, and sick leave from work due to stress [7].

The number of neurons and the size of cells in each auditory nucleus declines with age, with the neuronal population in the auditory cortex markedly less [13]. These alterations in the central auditory system are often due to hearing loss or attenuation of neural input from the peripheral auditory system. The speech interpretation centers of the brain need to process sounds into words, and if the ear cannot hear sounds, brain processing suffers. Loss of stimulation therefore results in reduced ability to understand speech.

Hearing aids are a simple and effective solution that provides the necessary stimulation required by the brain to understand everyday speech. As well as improving speech recognition, the brain provides plasticity to the hearing system. Satisfaction of a user of a sound amplification device may depend on a realization of the auditory limitations, cost, user expectations, fulfillment, functioning, auditory gains, and more importantly on the skill and knowledge of the audiologist [4]. Therefore, encouraging patients to use a hearing aid is very important.

The present study began by asking whether the period of hearing aid use by patients with hearing loss is important. If a hearing aid is used without delay, will the result be identical to a patient who decided to defer use of an aid. The current study looked at when patients began to use a hearing aid, comparing those who delayed their use with those who used them as soon as their hearing loss was diagnosed. There were thus two groups of patients: the first group was patients who refused to use hearing aids because they believed their problem was not serious. The second group decided to use hearing aids when their hearing started to decrease.

\section{Material and methods}

In the current study, 204 patients aged $45-85$ years old who attended a private audiology clinic for hearing impairment during 2000-18 were evaluated. Patients who had a neurological disorder or conductive hearing loss were excluded from the study. The gender of the patients was not considered. All patients in the study were diagnosed with bilateral sensorineural hearing loss. The patients were classified into two groups: the first group declined to use a hearing aid (Unaided group) and the second group decided to use them as a bilateral pair (Aided group). Impedance audiometry showed normal tympanograms (otherwise, patients were excluded). The patients wore their hearing aids 8-10 hours a day. The follow-up was 36 months following the patient's first attendance (longer times were not possible because of access limitations). Evaluations were performed at the beginning, 18 months, and 36 months following the patient's first diagnosis.

Examinations were carried out using an acoustic soundproof booth equipped with a pre-cabin for the operator and a 2-channel Aurical Hearing Instrument Test (HIT). Acoustic reflex testing and tympanometry was conducted with a Madsen OTOflex 100 OTOdiagnostics. Otoscopy was also performed on all subjects to ensure that no visible external or middle ear abnormality was present on the day of the test. Speech audiometry was carried out using live voice at $40 \mathrm{~dB} \mathrm{HL}$.

Pure-tone audiometry measured air conduction thresholds for each ear at 250, 500, 1000, 2000, 4000, 6000, and $8000 \mathrm{~Hz}$ [14]; bone conduction thresholds for each ear were measured at 250, 500, 1000, 2000, and $4000 \mathrm{~Hz}$.

The speech reception threshold (SRT) is the ability of the patient to perceive standardized two-syllable words, while the speech discrimination score (SDS) is the ability to respond to standardized monosyllabic words [15]. The SRT test was based on the Persian-language version of a staggered spondaic word list comprising two syllables with equal emphasis on each syllable. Two lists were used for each test condition [16]. The lowest intensity at which the patient was able to correctly repeat $50 \%$ of the spondees was defined as the SRT. The SDS, also called the word recognition score, indicates the patient's ability to hear and understand speech at typical conversational levels. Patients were tested in their native language (Persian). To perform SDS, 25 unfamiliar single syllable words at $40 \mathrm{~dB}$ above the SRT were presented to the patient. SDS was determined as the level of discrimination between phonemes which the patient understood and repeated correctly [17]. Speech audiometry tests were presented as "monitored live-voice".

Aided groups were fitted with hearing aids and were very happy with the outcome of the treatment. They returned about 1-3 weeks following their first hearing aid fitting. The proper care, use, and maintenance of the hearing aids were reviewed.

\section{Results}

Examinations were carried out at the beginning, 18 months, and 36 months following their first diagnosis. Evaluations of PTA, impedance audiometry, SRT, and SDS score were done. Patients were divided into two groups. The first group included 102 patients where hearing aids were applied early (immediately after diagnosis of hearing loss). The other 102 patients declined to use hearing aids. There was no 
Table 1. Demographic findings among Unaided and Aided groups

\begin{tabular}{ccccc}
\hline \multirow{2}{*}{ Parameter } & & Total & \multicolumn{2}{c}{ Group } \\
\cline { 3 - 5 } & & & Unaided & Aided \\
\hline \multirow{2}{*}{ Age } & Mean \pm SD & $66.8 \pm 4.5$ & $66.8 \pm 4.5$ & $66.9 \pm 4.5$ \\
\cline { 2 - 5 } & Median (range) & $66(56-78)$ & $66(56-78)$ & $66(58-77)$ \\
\hline Sex & F & $102(50.5 \%)$ & $54(53.5 \%)$ & $0.888+$ \\
\cline { 2 - 5 } & $\mathrm{M}$ & $100(49.5 \%)$ & $47(46.5 \%)$ & $53(52.5 \%)$ \\
\hline
\end{tabular}

† Based on $t$-test

* Based on chi-square test

significant difference between the aided and unaided groups in terms of age or gender.

\section{Statistical methods}

The mean, standard deviation, median and range, and frequency and range were analysed. A $t$-test and chi-square test were used to compare characteristics of the patients in the two groups. A linear mixed model was used to compare the groups so as to take account of correlations between the two ears. In addition, another linear mixed model was used to adjust the baseline values when comparing the two groups. The interaction of the time and treatment groups in the linear mixed model indicates whether there is a significant difference between the two groups. All statistical analyses were performed by SPSS Statistics for Windows, Version 25.0 (IBM Corp, Armonk, N.Y., released 2017). A p-value less than 0.05 was considered statistically significant.

As can be seen in Table 1, there was no statistically significant difference between the two groups regarding their age $(p=0.89)$ or $\operatorname{sex}(p=0.40)$.

Table 2 indicates the difference between the two groups in terms of frequency and follow up times. Based on these results, there is no statistically significant difference between the two groups for frequencies of 250,500, 1000, 2000, and $4000 \mathrm{~Hz}$ in the baseline or in the follow up after adjustment for the baseline values (all $p$-values $>0.05$, see Table 2 ). On the other hand, there was a statistically significant difference between the two groups in the baseline values of frequency $8000 \mathrm{~Hz}(p=0.001)$. Also, after adjustment of the baseline values, there was a statistically significant difference between the two groups in this frequency in the 18th month $(p=0.020)$. This adjusted statistically significant difference diminished after 18 months and in the 36th month it was no longer statistically significant $(p=0.254)$.

To take account of possible correlations of the measurements in the two ears of a person we used a linear mixed model. There was no statistically significant difference between the two groups at baseline in SRT $(p=0.084)$ or SDS $(p=0.577)$. For SRT, the baseline-adjusted difference between the two groups was 0.1 (95\% CI: -2.0 to $2.2, p=0.592)$ at 18 months and 0.4 (95\% CI: -1.7 to $2.3, p=0.748)$ at 36 months, which were not statistically significant. To adjust for the effect of baseline shifts when comparing the groups at different follow ups, we used a linear mixed model which took account
Table 2. Hearing test results at three times for the two groups for frequencies from 250 to $8000 \mathrm{~Hz}$

\begin{tabular}{|c|c|c|c|c|}
\hline \multirow{2}{*}{$\begin{array}{l}\text { Frequency } \\
(\mathrm{Hz})\end{array}$} & \multirow{2}{*}{$\begin{array}{c}\text { Time } \\
\text { (months) }\end{array}$} & \multicolumn{2}{|c|}{ Group } & \multirow{2}{*}{$p$} \\
\hline & & Unaided & Aided & \\
\hline \multirow{3}{*}{250} & 0 & $51 \pm 9$ & $52 \pm 8$ & $0.084 \neq$ \\
\hline & 18 & $51 \pm 9$ & $53 \pm 8$ & $0.942 \S$ \\
\hline & 36 & $52 \pm 9$ & $53 \pm 8$ & $0.302 \S$ \\
\hline \multirow{3}{*}{500} & 0 & $55 \pm 9$ & $55 \pm 8$ & $0.577 \neq$ \\
\hline & 18 & $56 \pm 9$ & $56 \pm 8$ & $0.763 \S$ \\
\hline & 36 & $57 \pm 9$ & $56 \pm 8$ & $0.214 \S$ \\
\hline \multirow{3}{*}{1000} & 0 & $56 \pm 10$ & $55 \pm 10$ & $0.726 \neq$ \\
\hline & 18 & $56 \pm 10$ & $55 \pm 10$ & $0.724 \S$ \\
\hline & 36 & $58 \pm 11$ & $56 \pm 10$ & $0.258 \S$ \\
\hline \multirow{3}{*}{2000} & 0 & $58 \pm 10$ & $57 \pm 10$ & $0.587 \neq$ \\
\hline & 18 & $58 \pm 10$ & $58 \pm 10$ & $0.760 \S$ \\
\hline & 36 & $61 \pm 11$ & $59 \pm 10$ & $0.163 \S$ \\
\hline \multirow{3}{*}{4000} & 0 & $59 \pm 11$ & $58 \pm 11$ & $0.172 \neq$ \\
\hline & 18 & $60 \pm 12$ & $59 \pm 11$ & $0.422 \S$ \\
\hline & 36 & $63 \pm 12$ & $59 \pm 11$ & $0.070 \S$ \\
\hline \multirow{3}{*}{8000} & 0 & $63 \pm 13$ & $61 \pm 12$ & $0.001 \neq$ \\
\hline & 18 & $64 \pm 13$ & $62 \pm 13$ & $0.020 \S$ \\
\hline & 36 & $67 \pm 14$ & $64 \pm 13$ & $0.254 \S$ \\
\hline
\end{tabular}

\# Based on a linear mixed model considering the correlation of outcomes of both ears

$\S$ Based on a linear mixed model adjusted for difference in baseline

of the interaction between time and groups. After adjusting for baseline, the difference in SDS between the two groups was observed to be 1.7 ( $95 \% \mathrm{CI}:-0.8$ to $4.3, p=0.180$ ), which was not statistically significant.

On the other hand, the adjusted difference between the two groups was found to be statistically significant (adjusted difference of 8.6 ; $95 \%$ CI: 5.6 to $10.7, p<0.001$ ). This finding is set out in Table 3 and Figures 1 and 2.

Based on these results, there was no statistically significant difference between the two groups for frequencies of $250,500,1000,2000$, and $4000 \mathrm{~Hz}$ in the baseline or in the 
Table 3. Speech performance results between the two groups

\begin{tabular}{|c|c|c|c|c|c|c|c|}
\hline \multirow{2}{*}{ Frequency } & \multirow{2}{*}{ Time } & \multicolumn{2}{|c|}{ Group } & \multirow{2}{*}{ Diff } & \multicolumn{2}{|c|}{$95 \% \mathrm{Cl}$} & \multirow{2}{*}{$p$} \\
\hline & & Unaided & Aided & & Lower & Upper & \\
\hline \multirow{5}{*}{ SRT } & 0 & $53.8 \pm 6.8$ & $53.2 \pm 6.3$ & & & & $0.084 \ddagger$ \\
\hline & 18 & $54.6 \pm 7.1$ & $54.2 \pm 6.6$ & & & & \\
\hline & $18-0$ & $0.8 \pm 2.9$ & $0.9 \pm 3.3$ & 0.1 & -2.0 & 2.2 & $0.592 \S$ \\
\hline & 36 & $57.1 \pm 8$ & $56.3 \pm 7.8$ & & & & \\
\hline & $36-0$ & $2.5 \pm 5.4$ & $2.1 \pm 5.9$ & 0.4 & -1.7 & 2.3 & $0.748 \S$ \\
\hline \multirow{5}{*}{ SDS } & 0 & $81.5 \pm 8.9$ & $80.6 \pm 9$ & & & & $0.577 \ddagger$ \\
\hline & 18 & $80.7 \pm 9.1$ & $81.4 \pm 9.7$ & & & & \\
\hline & $18-0$ & $-0.8 \pm 2.4$ & $0.8 \pm 1.8$ & 1.7 & -0.8 & 4.3 & $0.180 \S$ \\
\hline & 36 & $73.2 \pm 8.7$ & $82.5 \pm 9.7$ & & & & \\
\hline & $36-0$ & $-7.5 \pm 6.1$ & $1.1 \pm 2.3$ & 8.6 & 5.6 & 10.7 & $<0.001 \S$ \\
\hline
\end{tabular}

₹ Based on a linear mixed model considering the correlation of the outcome of both ears

$\S$ Based on a linear mixed model adjusted for difference in baseline, evaluated by interaction of time and group

follow up after adjustment for the baseline values (all $p$-values $>0.05$, see Table 2 ). On the other hand, there was a statistically significant difference between the two groups in the baseline values of frequency $8000 \mathrm{~Hz}(p=0.001)$. Also, after adjustment of the baseline values there was a statistically significant difference between the two groups for this frequency in month $18(p=0.020)$. This adjusted statistically significant difference diminished after 18 months and in month 36 it was not statistically significant any more $(p=0.254)$ (Table 2).

There was no statistically significant difference between the two groups at baseline in SRT $(p=0.084)$ nor SDS $(p=0.577)$. The baseline adjusted difference between the two groups in SRT was 0.1 (95\% CI: -2.0 to $2.2, p=0.592$ ) and 0.4 (95\% CI: -1.7 to $2.3, p=0.748)$ in months 18 and 36 , respectively, which were not statistically significant. We adjusted the effect of the baseline in the comparison

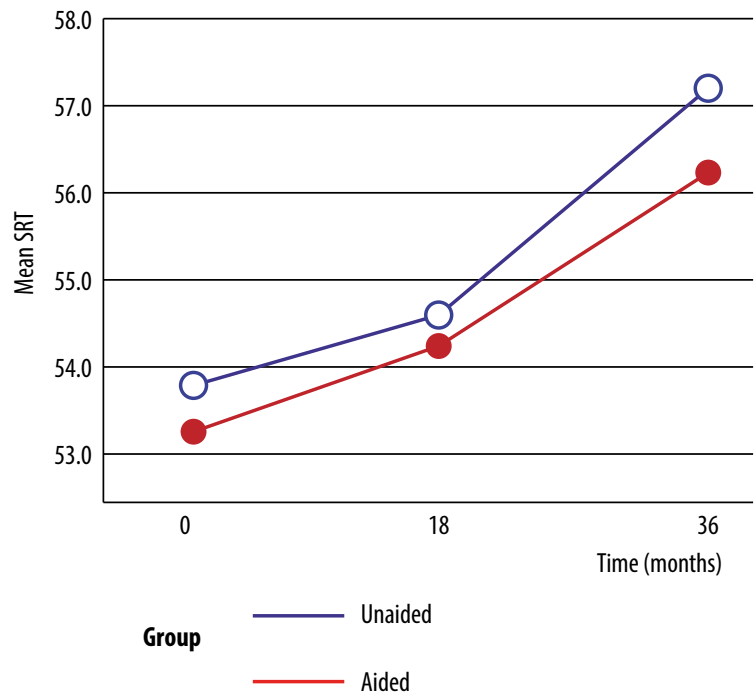

Figure 1. Difference between the two groups in speech reception threshold (SRT) of the groups in different follow ups using the interaction of the time and groups within a linear mixed model. After adjustment for the baseline, the difference of SDS between the two groups was observed to be 1.7 (95\% CI: -0.8 to $4.3, p=0.180)$, which was not statistically significant.

On the other hand, the adjusted difference between the two groups was found to be statistically significant (adjusted difference of $8.6,95 \%$ CI: 5.6 to $10.7, p<0.001$ ). These findings are illustrated in Table 3 and Figures 1 and 2.

\section{Discussion}

Hearing loss has often been underestimated, but it can potentially lead to a range of negative physical, cognitive, and behavioral effects as well as an increase in daily life risks arising from problems in communication and language acquisition. The effects are also plainly connected to dementia

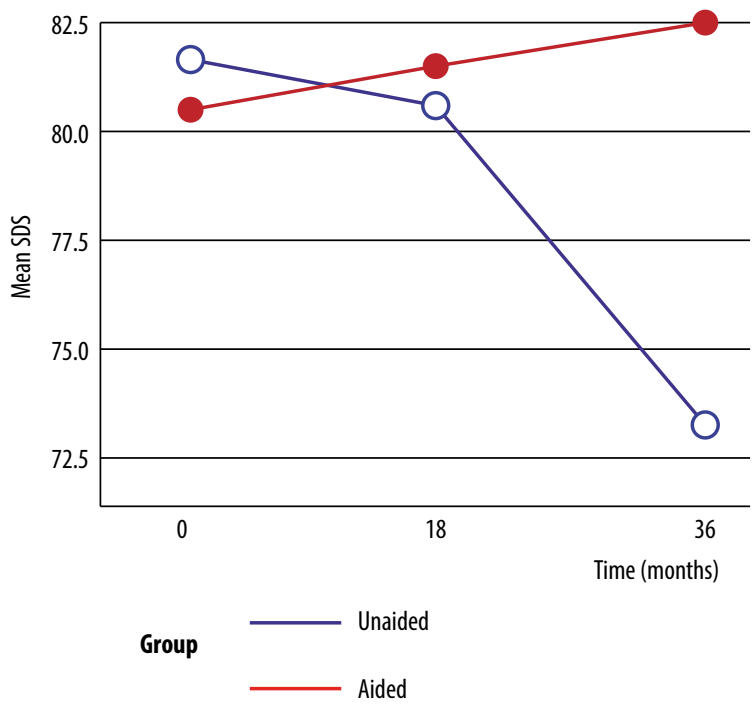

Figure 2. Difference between the two groups in speech discrimination score (SDS) 
and depression. Because of the prevalence of environmental noise and an increase in the elderly population, the number of people with hearing loss has grown rapidly in recent years. Many people are unaware of signs of early hearing loss. Hearing impairment degrades the interior representation of acoustic stimuli [18], and consequently hearing-impaired listeners experience difficulties in speech recognition [8].

In this study we evaluated the effect of the early application of hearing aids on speech discrimination capabilities. PTA, SRT, and SDS scores of 204 patients who attended an audiology clinic were measured over a 36-month period. The results show that, at 36 months, the patients who used hearing aids had better SDS scores compared to the patients who declined to use hearing aids. In spite of hearing loss in all patients after 36 months (as measured by SRT scores), the aided group still presented better SDS scores. That is, hearing at measured frequencies decreased in both the aided and unaided groups, but speech perception was still better in the aided group compared to the unaided group. This indicates that timely application of hearing aids can prevent deterioration of speech recognition.

It has been noted that hearing-impaired listeners suffer unfavorable speech perception compared with normal listeners $[10,19,20]$. The cognitive pressure of the listening task is increased by trying to keep up with the processing of continuous auditory streams [11]. Consequently, hearing-impaired listeners need to expend additional effort to successfully perceive speech $[8,12]$. Extra listening effort can potentially lead to adverse psychosocial costs, such as higher levels of mental distress and fatigue [21-23], energy shortfalls, and stress-related sick leave from work [23-26]. Nachtegaal et al. (2009) reported a positive relationship between reduced hearing thresholds and the need for recovery after a working day. Furthermore, people's social interactions and quality of life can be significantly altered by hearing impairment because of withdrawal from relaxation and community engagement [27-29], and the extra effort needed for successful listening can be a factor in this. The concept of listening effort and its relation with hearing impairment has gained increasing attention from clinicians and researchers [7, 30, 31].

A meta-analysis carried out by Taljaard et al. suggested that hearing impairment is connected to cognitive issues. However, they reported that this assumption could be premature considering the variation between studies, small sample sizes, and inability to control health factors [32]. They concluded that people with hearing loss have more cognitive issues compared to normals, even though treatment of the hearing loss did not make a significant difference. However, according to our results, speech perception ability can at least be preserved in hearing impaired individuals by early use of hearing aids - before the onset of a drop in speech perception.

There is a huge body of research on applying hearing aids in patients suffering from hearing loss. However, there is no clear data about the best time to opt for a hearing aid. The current study examined the use of hearing aids during the early stage of hearing loss diagnosis. According to our results, patients could delay using a hearing aid until their speech perception starts to decline. However, hearing aids will be essential after their speech perception begins to decrease. We believe the golden time of using hearing aids is actually before the start of speech perception loss since the patient will then benefit the most. According to our findings, patients who started employing hearing aids before their speech perception decreased faced lower rates of speech perception decline. In comparison, the rate of decline was higher in patients who declined to use hearing aids.

\section{Conclusion}

People suffering hearing loss have difficulties understanding speech. Diminished speech understanding affects everyday life and it cannot be easily restored. Early application of hearing aids and the subsequent effects on speech understanding were addressed in the present study. Patients who declined early application of hearing aids were found to have lower SDS scores at 36 months compared to patients who used hearing aids early. It seems that some patients delay employing hearing aids until their speech perception capabilities begin to decrease, but the golden time for hearing aids application is before the onset of speech perception loss.

\section{Acknowledgement}

The author thanks all participants for taking part in the study.

\section{References}

1. Arlinger S. Negative consequences of uncorrected hearing loss: a review. Int J Audiol, 2003; 42 (Suppl 2): 2S17-2S20.

2. Engdahl B, Idstad M, Skirbekk V. Hearing loss, family status and mortality: findings from the HUNT study, Norway. Soc Sci Med, 2019; 220: 219-225.

3. Itoh A, Nakashima T, Arao H, et al. Smoking and drinking habits as risk factors for hearing loss in the elderly: epidemiological study of subjects undergoing routine health checks in Aichi, Japan. Public Health, 2001; 115(3): 192-6.

4. José MR, Campos PD, Mondelli MF. Unilateral hearing loss: benefits and satisfaction from the use of hearing aids. Braz J Otorhinolaryngol, 2011; 77(2): 221-8.

5. Gallacher J. Hearing, cognitive impairment and aging: a critical review. Rev Clin Gerontol, 2004;14(3): 199-209.

6. Harrison Bush AL, Lister JJ, Frank RL, Betz J, Edwards JD. Peripheral hearing and cognition: evidence from the Staying Keen in Later Life (SKILL) study. Ear Hear, 2015; 36(4): 395-407.

7. Ohlenforst B, Zekveld AA, Jansma EP, et al. Effects of hearing impairment and hearing aid amplification on listening effort: a systematic review. Ear Hear, 2017; 38(3): 267-81.

8. McCoy SL, Tun SL, Cox PA, et al. Hearing loss and perceptual effort: downstream effects on older adults' memory for speech. Q J Exp Psychol A, 2005; 58(1): 22-33.

9. Hällgren M, Larsby B, Lyxell B, Arlinger S. Speech understanding in quiet and noise, with and without hearing aids: Int $\mathrm{J} \mathrm{Au-}$ diol, 2005; 44(10): 574-83. 
10. Hopkins K, Moore BC, Stone MA. Effects of moderate cochlear hearing loss on the ability to benefit from temporal fine structure information in speech. J Acoust Soc Am, 2008; 23(2): 1140-53.

11. Shinn-Cunningham BG, Best V. Selective attention in normal and impaired hearing. Trends Amplif, 2008;12(4): 283-99.

12. Rönnberg J, Lunne T, Zekveld A, et al., The Ease of Language Understanding (ELU) model: theoretical, empirical, and clinical advances. Front Syst Neurosci, 2013, 7: 31.

13. Willott JF. Aging and the Auditory System. San Diego, CA: Singular Publishing Group, 1991.

14. British Society of Audiology. Recommended procedure. Pure tone air conduction and bone conduction threshold audiometry with and without masking, 2011.

15. Roeser, RJ, Valente M, Hosford-Dunn H. Diagnostic procedures in audiology. In: Audiology: Diagnosis $\left(2^{\text {nd }} e d\right)$, Thieme, New York, 2007, 1-16.
16. Podlesek A, Komidar L, Sočan G, et al. A comparative analysis of different procedures for measuring speech recognition threshold in quiet. Psihološka Obzorja, 2008; 17(4): 33-49.

17. Caswell KL. Test-Retest Reliability of Speech Recognition Threshold Material in Individuals with a Wide Range of Hearing Abilities. Dissertation, Brigham Young University, 2013.

18. Humes LE. Speech understanding in the elderly. J Am Acad Audiol, 1996; 7: 161-7.

19. Hagerman B. Clinical measurements of speech reception threshold in noise. Scand Audiol, 1984; 13(1): 57-63.

20. Plomp R. A signal-to-noise ratio model for the speech-reception threshold of the hearing impaired. J Speech Lang Hear Res, 1986; 29(2): 146-54.

21. Stephens D, Hétu R. Impairment, disability and handicap in audiology: towards a consensus. Audiology, 1991; 30(4): 185-200. 